\title{
Generating Marker-Free Transgenic Wheat Using Minimal Gene Cassette and Cold-Inducible Cre/Lox System
}

ARTICLE in PLANT MOLECULAR BIOLOGY REPORTER • OCTOBER 2015

Impact Factor: $2.37 \cdot$ DOI: 10.1007/s11105-014-0830-1

DOWNLOADS

68
VIEWS

114

9 AUTHORS, INCLUDING:

Klára Mészáros

Hungarian Academy of Sciences

32 PUBLICATIONS 340 CITATIONS

SEE PROFILE

\section{Ildikó Karsai}

Agricultural Research Centre of the Hungaria. .

58 PUBLICATIONS 746 CITATIONS

SEE PROFILE
Csaba Éva

Agricultural Institute, Centre for Agricultural ...

7 PUBLICATIONS 10 CITATIONS

SEE PROFILE

Laszlo Tamas

Eötvös Loránd University

67 PUBLICATIONS 472 CITATIONS

SEE PROFILE 


\section{Plant Molecular Biology Reporter \\ Generating marker-free transgenic wheat using minimal gene cassette and cold inducible Cre/lox system \\ --Manuscript Draft--}

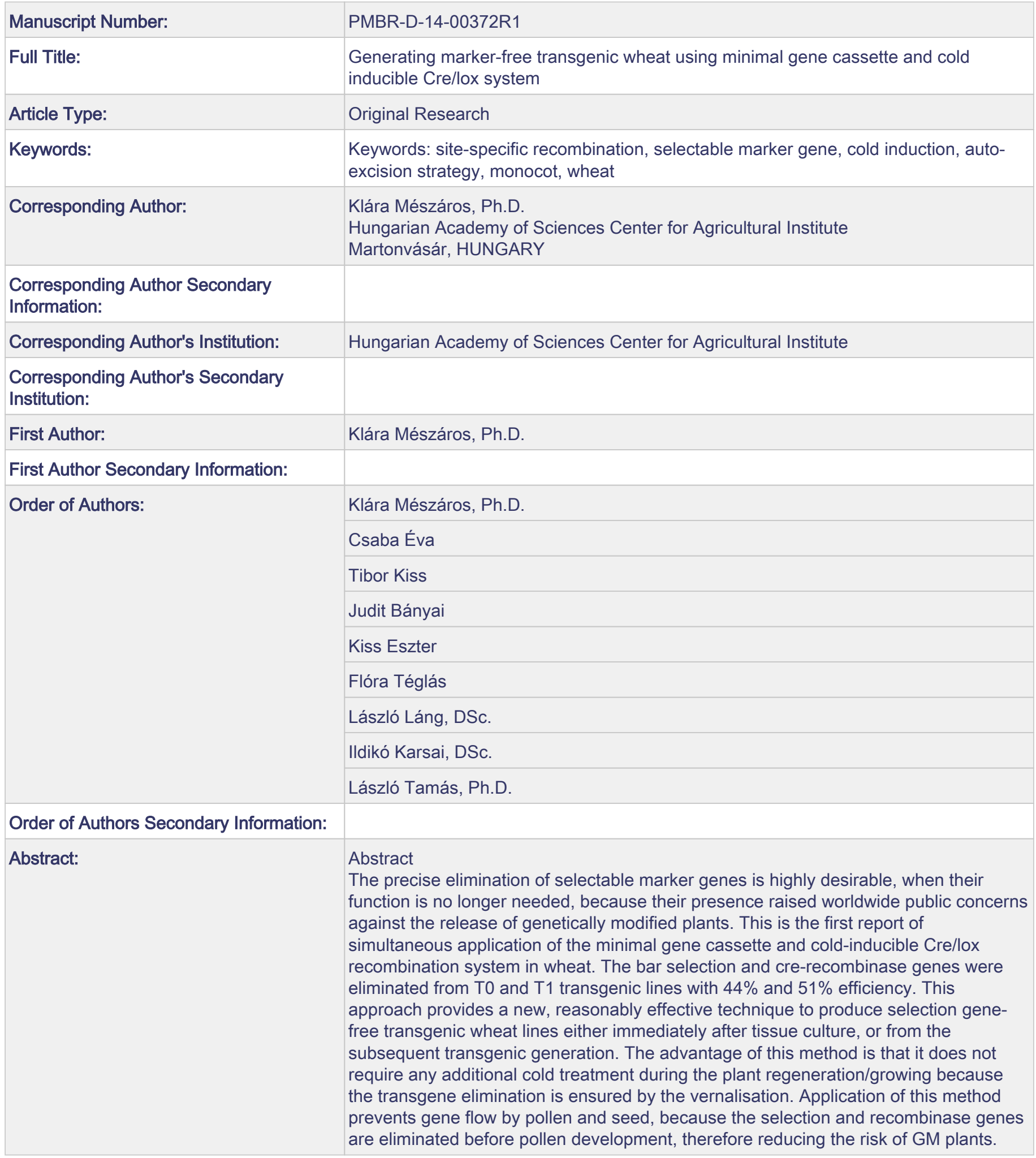




\begin{abstract}
The precise elimination of selectable marker genes is highly desirable, when their function is no longer needed, because their presence raised worldwide public concerns against the release of genetically modified plants. This is the first report of simultaneous application of the minimal gene cassette and cold-inducible Cre/lox recombination system in wheat. The bar selection and cre-recombinase genes were eliminated from $\mathrm{T}_{0}$ and $\mathrm{T}_{1}$ transgenic lines with $44 \%$ and $51 \%$ efficiency. This approach provides a new, reasonably effective technique to produce selection gene-free transgenic wheat lines either immediately after tissue culture, or from the subsequent transgenic generation. The advantage of this method is that it does not require any additional cold treatment during the plant regeneration/growing because the transgene elimination is ensured by the vernalisation. Application of this method prevents gene flow by pollen and seed, because the selection and recombinase genes are eliminated before pollen development, therefore reducing the risk of GM plants.
\end{abstract}

\title{
Introduction
}

Genetic modification has become routine for a growing number of plant species. It is no question therefore, how to introduce foreign genes into the host genome. However precise incorporation and controlled expression still present a challenge, because the most efficient methods allow random introduction of transgenes into the plant genome generating unpredictable effects on both transgene and native gene expression (Gidoni et al. 2008). Beside to the appropriate gene expression, the risk of utilization of transgenic plant would be decreased by controlling gene integration and transcription and thus the public concerns would be appeased.

The most controversial parts of the transformation systems are the selectable marker genes, especially antibiotic and herbicide resistance genes which are used to differentiate transgenic from non-transgenic lines. Several alternative methods have been elaborated for marker free transgenic plant production, as positive selection, a strategy that gives transgenic cells a metabolic advantage over non-transgenic cells (Reed et al. 2001; Zhu et al. 2008). Another approach is the selective elimination of selectable marker sequences from the transgenic plant when they are no longer needed. Foremost the normal segregation of cotransformed selection gene and gene of interest (GOI) were used (Matthews et al. 2001). Because of its simplicity, this method is widely used in different plant species, but it is

Keywords: site-specific recombination, selectable marker gene, cold induction, auto-excision strategy, monocot, wheat

\section{Klára Mészáros ${ }^{1}$, Csaba Éva $^{1}$, Tibor Kiss ${ }^{1}$, Judit Bányai $^{1,}$ Eszter Kiss $^{2}$, Flóra Téglás ${ }^{2}$, László Láng ${ }^{1}$, Ildikó Karsai ${ }^{1}$, László Tamás ${ }^{2}$ \\ ${ }^{2}$ Agricultural Research Center of the Hungarian Academy of Sciences, Martonvásár, Hungary
${ }^{2}$ Department of Plant Physiology and Molecular Plant Biology, Eötvös Lorand University, Hungary \\ Generating marker-free transgenic wheat using minimal gene cassette and cold inducible Cre/lox system \\ Corresponding author: Klára Mészáros meszaros.klara@agrar.mta.hu}

Because of its simplicity, this method is widely used in different plant species, but it is 
laborious and time consuming because of the several selection steps in progeny generations. selective elimination unfeasible. Another option for marker gene elimination is the transposon mediated removal, which however also requires further segregation steps (Cotsaftis et al. 2002). An additional method is the site-specific recombination which proved to be the most efficient way of marker gene elimination because of its relative simplicity. The natural function of these systems is the control of the precise excision or integration of defined DNA units into the host genome (Gidoni et al. 2008; Nandy and Srivastava 2012). The phage mediated recombination was successfully used in plant biotechnology (Kempe et al. 2010; Kittiwongwattana et al. 2007). The sifting characterised systems used in plants and other organisms are Cre/lox of bacteriophage P1 of Escherichia coli (Hoa et al. 2002; Hoess et al. 1985; Sternberg and Hamilton 1981), R/RS from the SR1 plasmid of Zygosaccharomyces rouxii, and FLP/FRT from the 2- $\mu \mathrm{m}$ plasmid of Saccharomyces cerevisiae (Akbudak and Srivastava 2011; Hu et al. 2008). The Cre and FLP recombinases are members of the tyrosine recombinase family (Gilbertson 2003). The accurate integration or excision requires a pair of identical recognition target sites. The structure of the sites are palindromic, $34 \mathrm{bp}$ or $31 \mathrm{bp}$ in loxP, FRT and RS, respectively, containing two inverted repeats (12-13 bp) which are linked by $7-8$ bp asymmetric spacer region. The enzyme recognises the palindrom sequence and cuts on the linking region. The most frequently used recombination approach in transgenic plants is the Cre/lox system. Recombination events have also been achieved in animal and plant systems (Kopertekh et al. 2004).

The prolonged expression of cre recombinase gene may cause adverse effects in the plants, such as leaf chlorosis, growth retardation, chromosomal aberrations and reduced proliferation (Coppoolse et al. 2003), therefore the strict regulation of manifestation is crucial. The limited expression of the recombinase gene can be achieved by using tissue specific, developmentally regulated or inducible promoters in self-excising cre-recombinase vectors (Gidoni et al. 2008). Numerous transformation systems, based on inducible promoters, were constructed, and used successfully for transgene elimination experiments in many species (Chong-Perez et al. 2012; 2013; Liu et al. 2005; Zuo et al. 2001). One of the most frequently used promoter is the heat inducible promoter which also proved to be the most efficient one, although its application is limited because of the thermal optimum of a given species. On the other hand low temperature is the natural part of the lifecycle and necessary for floral induction in many species especially in temperate overwintering cereals. Therefore the adaptation of the plants to low temperature is critical because it is one of the main abiotic stress factors. It is a complex process which results sweeping changes in gene expression, and de novo biosynthesis of stress-protective compounds (Kosová et al. 2012; Thomashow 1999). The genetic background of the low temperature adaptation was intensely studied. Several low temperature-responsive cDNA clones were characterized from wheat (Limnin et al. 1995). One of the most important group of cold-inducible dehydrins is the WCS120 (wheat coldspecific) protein family (Sarhan et al. 1997), which is represented by seven members (WCS200, WCS180, WCS120, WCS66, WCS40 WCS726 and WCS80), and display cryoprotective activities (Kosová et al. 2007, 2011, 2013). The most abundant member of this family is the WCS120 protein in cold-treated wheat. The wcs 120 gene is specifically activated by cold (Houde et al. 1992; Vitámvás et al. 2008), and the promoter analysis revealed that its expression is regulated by both ABA-dependent and ABA-independent signalling pathways (Sarhan et al. 1997). Other abiotic factors such as light, and water-stress also induced the wcs 120 gene, although the level of WCS120 protein was substantially reduced compared to cold induction (Houde et al.1992; Shen et al. 2003). The induction temperature and induction time depend on the genotype and growth habit (Kosová et al. 2013). 
The most frequently used vector during biolistic plant transformation is the circular which is responsible for several negative effects (Fu et al. 2000). Fu et al. (2000) achieved simple integration events with a low copy number and rear rearrangement by the application of the minimal transgene cassette, while realizing the same transformation efficiency as with the application of the whole plasmids. Moreover, the lack of the vector backbone sequences reduces the negative effect of transgene on endogenous gene expression (Fu et al. 2000; Vidal et al. 2006).

The aim of our research was to study whether the minimal transgene cassette based cold inducible Cre/lox recombination system is suitable for marker gene elimination from transgenic wheat directly after the tissue culture process before the transgenic plants produces any pollen, and whether there is any difference between the elimination efficiency in the $\mathrm{T}_{0}$ or $\mathrm{T}_{1}$ generation.

\section{Materials and methods}

\section{Plant transformation and regeneration Plant material and growth conditions}

Donor plants of the cv. "Cadenza" spring wheat variety were germinated for 3 days under dark condition, covered by wet filter paper, then were potted to Jiffy-7 pellet (www.jiffygroup.com) and were illuminated with $200 \mu \mathrm{molm}^{-2} \mathrm{~s}^{-1}$ light for 14 hours a day. The seedlings (Zadoks scale 11) were vernalised at $4^{\circ} \mathrm{C}$ for 2 weeks under low light intensity $\left(20 \mu \mathrm{molm}^{-2} \mathrm{~s}^{-1}\right)$. After the vernalisation, seedlings were raised at a day/night temperature of $18 / 16^{\circ} \mathrm{C}$ with 16 -h daylength in greenhouse (Global Glasshouse Venlo) under $200 \mu \mathrm{molm}^{-2} \mathrm{~s}^{-1}$ light intensity.

\section{Vector construction}

A transformation cassette (pKPK1) was assembled for biolistic plant transformation based on pGem-T-Easy vector (Promega). It was generated by sub-cloning the new DNA construct (Fig. 1.) into the single NotI restriction site of pGem-T-Easy vector. The new DNA construct is flanked by fragments originated from the 5' UTR of wheat glu- $1 D-1 d$ gene, raising the possibility of PCR-testing. The sequence of these two fragments is identical to X12928.5 from Gene bank, from nucleotide 2602 to 4279 . Other elements of the new DNA construct were ligated into the HindIII site of $g l u-1 D-1 d$ at base 3460, thereby separating the above fragment to two pieces of about 800 bp lengths. The new DNA construct contained the recombination cassette flanked by mutant lox sites, lox66 and 71 (Albert et al. 1995). The recombination cassette included the coding sequence of cre recombinase gene (Gene Bank accession number: X03453.1) under the control of wheat wcs120 promoter (AF031235) and the selectable marker gene bar under the control of maize ubiquitin promoter. The maize ubiquitin promoter-driven uidA (in this project it is considered as GOI) was inserted outside of the lox sites. All the three genes (cre, bar, uidA) were fused to Agrobacterium tumefaciens nos terminator. Linear DNA was used for biolistic plant transformation, similarly as it was published earlier by Loc et al. (2002). DNA fragment (Fig. 1.) was cut off from the pGem-TEasy based construct by NotI digestion and it was separated on agarose gel and purified from gel.

\section{Transformation}

Immature grains were collected 12-14 days after flowering, and were surface-sterilized with $70 \%$ (v/v) ethanol for $2 \mathrm{~min}$, then for $15 \mathrm{~min}$ in $10 \%(\mathrm{w} / \mathrm{v})$ Domestos with a few drops of Tween 20 followed by three rinses with sterile distilled water. The scutella, $1.5 \mathrm{~mm}$ size, were isolated and embryo axes were removed to prevent germination. Explants were placed scutellum side up onto callus induction medium. The nutrient media were prepared as 
described by Tamás et al. (2004) based on Sparks and Jones (2004) method. After keeping gun according to the manufacturer's instructions. A 28 Hgmm vacuum was created in the chamber and the helium $(\mathrm{He})$ gas was injected into the space above the macrocarrier at a pressure of $900 \mathrm{psi}$. Gold particles with a diameter of $0.6 \mu \mathrm{m}$ were suspended in ethanol at a density of $20 \mathrm{mg} / \mathrm{ml}$ and coated with pKPK1 linear DNA as described by Sparks and Jones (2004).

\section{Plant regeneration}

After bombardment the scutella were placed in fresh Petri dishes at an equal distance from each other and incubated in the dark at $23^{\circ} \mathrm{C}$ for three weeks. Scutella exhibiting callus formation were then transferred to shoot regeneration medium and kept in the light for a further three weeks. Root and shoot regeneration were induced by illumination with low intensity cool white light $\left(20 \mu \mathrm{molm}^{-2} \mathrm{~s}^{-1}\right)$ at a constant temperature of $23^{\circ} \mathrm{C}$. After three weeks, callies exhibiting plant regeneration were placed on shoot regeneration medium containing $2 \mathrm{mg} / \mathrm{l}$ phosphinotricin (ppt) for selection. The selection step was then repeated again with the same conditions. Efficiency of plant regeneration was evaluated in the $3^{\text {th }}-4^{\text {th }}$ week. Plant regeneration was expressed as the percentage of calli producing shoots compared with the number of embryos isolated. The survivor plants were planted onto Jiffy-7 pellet (www.jiffygroup.com).

\section{Cold treatment for Cre/lox activation}

In the first experiment the plantlets were regenerated then selected with $2 \mathrm{mg} / \mathrm{l}$ phosphinotricin (ppt). The $\mathrm{T}_{0}$ plants were acclimated by illumination with low intensity ( 20 $\mu$ molm ${ }^{-2} \mathrm{~s}^{-1}$ ) cool white light at a constant temperature of $23^{\circ} \mathrm{C}$ for seven days in Jiffy pellet. After the acclimatisation, seedlings were raised at a day/night temperature of $18 / 16^{\circ} \mathrm{C}$ with 16-h daylength in greenhouse under $200 \mu \mathrm{molm}^{-2} \mathrm{~s}^{-1}$ light intensity. The plants (Zadoks scale 14) were cold treated for two weeks at $+4^{\circ} \mathrm{C}$ under low light intensity $\left(20 \mu \mathrm{molm}^{-2} \mathrm{~s}^{-1}\right)$.

In the second experiment, the $T_{0}$ plants were regenerated by the same method as in the first but the selection agent (ppt) was already applied from the callus induction phase. The plantlets were cold treated immediately after the in vitro regeneration (Zadoks scale 11) for two weeks at $+4^{\circ} \mathrm{C}$ under low light intensity $\left(20 \mu \mathrm{molm}^{-2} \mathrm{~s}^{-1}\right)$.

In the third experiment the $T_{0}$ plants were regenerated in the same way as in the first experiment, but after acclimatisation the plants were grown up without any cold treatment at a day/night temperature of $18 / 16^{\circ} \mathrm{C}$ with 16 -h day length in greenhouse (Global Glasshouse Venlo) under $200 \mu \mathrm{molm}^{-2} \mathrm{~s}^{-1}$ light intensity.

The germinated $T_{1}$ seeds were potted to Jiffy-7 pellet and were illuminated with $200 \mu \mathrm{molm}{ }^{-2}$ $\mathrm{s}^{-1}$ light for 14 or 16 hours a day. The $\mathrm{T}_{1}$ seedlings (Zadoks scale 11) were vernalised at $+4^{\circ} \mathrm{C}$ for two weeks under low light intensity $\left(20 \mu \mathrm{molm}^{-2} \mathrm{~s}^{-1}\right)$. After vernalisation, the seedlings were raised at a day/night temperature of $18 / 16^{\circ} \mathrm{C}$ with 16 -h day length in greenhouse under $200 \mu \mathrm{molm}^{-2} \mathrm{~s}^{-1}$ light intensity.

\section{Transgene detection}

\section{Assay for GUS activity}

The GUS expression level was determined on explants sampled after 3 weeks of callus induction using the histochemical GUS assay as described by Wu et al. (2003). Explants were incubated overnight at $37^{\circ} \mathrm{C}$ in buffer containing $1 \mathrm{mM}$ X-Gluc, $100 \mathrm{~m} M$ sodium phosphate buffer ( $\mathrm{pH} 7.0$ ), $0.5 \mathrm{~m} M$ potassium ferricyanide, $0.5 \mathrm{~m} M$ potassium ferrocyanide and $0.1 \%$ (v/v) Triton X-100. Blue spots were visually observed under the microscope.

\section{Transgene detection by molecular markers}




\section{DNA isolation}

Genomic DNA was isolated from the leaf tissue of $\mathrm{T}_{0}$ and $\mathrm{T}_{1}$ plants before and after cold treatment by Qiagen DNA isolation kit. DNA quality and quantity were determined by NANODROP 1000 spectrophotometer.

\section{PCR reaction}

The presence/absence of transgenes was detected in three replications. PCR-reactions were carried out in $15 \mu \mathrm{l}$ volumes containing 20-40 ng genomic plant DNA, $1 \times$ Taq buffer (Fermentas), $0.5-1 \mu \mathrm{M}$ primers, $1 \mathrm{mM}$ dNTPs, and $1 \mathrm{U}$ Taq polymerase (Fermentas). PCR reaction of primer pair 1,3,5 and 6 was performed by the following program: denaturation at $94{ }^{\circ} \mathrm{C}(5 \mathrm{~min}) ; 30$ cycles of amplification at $94{ }^{\circ} \mathrm{C}(40 \mathrm{~s})$, annealing $(30 \mathrm{~s})$, elongation $74{ }^{\circ} \mathrm{C}$ (40 s) per cycle; and a final elongation step of $72{ }^{\circ} \mathrm{C}$ for $7 \mathrm{~min}$. The uidA gene was detected either by primer pair 1 , overlapping the $u b i$ promoter - uidA transgene border, or by the primer pair 2 described by Wu et al. (2003). This latter primer pair covers the coding region of uidA gene from base 379 to 1431 . For the bar gene detection, two primer pairs were also applied. Primer pair3, overlapping the bar gene and the nos terminator, while the primer pair4 described by Wu et al. (2003.), covering the coding region from base 61 to 504. The presence of cre gene was detected by the primer pair 5. The forward primer attaches to the 3' end of wcs 120 promoter, while the reverse primer links to the 5' end of cre-recombinase gene, and the product size is $600 \mathrm{bp}$. Site-specific recombination events were also detected by PCR, using primer pair 6 . The amplified fragment overlaps the recombination region. The PCRproduct expected to be amplified if recombination occurred is $350 \mathrm{bp}$ otherwise a $5400 \mathrm{bp}$ is amplified from the original $\mathrm{KG1-Vec8}$ cassette in principle. This latter product is however highly unlikely to be produced because of the defaults of this PCR-program, i.e. elongation for $40 \mathrm{~s}$. The sequences of all the primers are listed in Table 1 and their binding sites are shown in Fig. 1.

\section{Excision footprint sequencing analysis}

Vector-cloned fragments were sequenced by using Big Dye Terminator technology (Life Technologies). Sequences were compared to sequences deposited in Gene bank by using the Emboss program (http://www.ebi.ac.uk/Tools/emboss/)

\section{Results}

\section{Plant transformation, regeneration and transgene detection}

In order to study the efficacy of wcs 120 promoter for the induction of cre gene in a selection marker gene excision system, a transformation cassette (called pKPK1) was assembled. This transformation cassette consisted of two DNA fragments. The so called recombination part was flanked by mutant lox sites (lox 66 and lox71), while the other part is considered to be the GOI. The recombination part included the cre recombinase gene under the control of the cold inducible wcs 120 promoter and the bar gene driven by the constitutive ubiquitin promoter. The ubiquitin promoter-driven uidA gene was chosen as the gene of interest in this experiment because it was easy to study its activity on the protein level. Plant material was produced for the recombination experiments, by transforming spring wheat $\mathrm{cv}$ "Cadenza" immature embryos with pKPK1, using biolistic method in three independent transformation experiments, differing in the way of selection. The competency for PCR of genomic DNA, extracted from the regenerated plants was tested using Ppd-D1 primer pair which attaches to the endogenous wheat $P p d-D l$ photoperiod sensitivity gene on the short arm of 2D chromosome. PCR-positive samples to this gene were included exclusively in further analyses. The presence of the uidA, the cre recombinase and the bar genes were 
followed in the regenerated plantlets, by using primer pairs 1-2, 3-4, and 5, respectively (Table 1.).

In the first transformation experiment, 2400 immature embryos were transformed. In total, 63 plantlets survived both selections. DNA was isolated from these plantlets (Zadock scale 12). Not all the phosphinotricin selected plants proved to be transgenic according to PCR based screening. The specific bands of uidA and bar genes were visible in 40 lines which means $1.66 \%$ transformation efficiency. 38 of them were cold treated and two were used as untreated control (Table 2.). There were two transgenic lines $\left(1 \mathrm{~T}_{0} / 2,1 \mathrm{~T}_{0} / 5\right)$ lacking crerecombinase gene but harbouring both uidA and bar genes

In the second transformation experiment 1800 immature cv "Cadenza" embryos were involved. The selection was carried out at the beginning of the callus induction. After three weeks of callus induction, the uidA gene activity was scored by GUS histochemical assay. $64 \%$ of the calli showed positive reaction. Overall 67 plants were regenerated. DNA was isolated from the leaves segments after the plant selection (Zadoks scale 11) during in vitro plant regeneration. Twenty-nine of 67 plantlets survived the cold treatment, that were included in the further examinations. The transformation efficiency was $1.55 \%$ in this experiment.

The specific product proving the presence of the uidA gene was identified in 24 transgenic lines (Table 2). The whole transformation cassette was missing only from one line $\left(2 \mathrm{~T}_{0} / 3\right)$. There was incomplete integration in further three lines. The uidA gene failed to incorporate into the $2 \mathrm{~T}_{0} / 4$ and $2 \mathrm{~T}_{0} / 25$ lines, while the recombination cassette was absent from the $2 \mathrm{~T}_{0} / 12$ line. Interestingly there are three progenies carrying the bar gene, where the cre recombinase is missing $\left(2 \mathrm{~T}_{0} / 1,2 \mathrm{~T}_{0} / 10,2 \mathrm{~T}_{0} / 11\right)$. We used these lines as control in the further recombination experiments.

In the third experiment setup $1400 \mathrm{cv}$ "Cadenza" immature embryos were transformed. Three days after the transformation the presence of uidA gene was monitored by GUS assay as described by Wu et al. (2003). Transient gene expression was detected in $26 \%$ of the calli. 1100 plantlets were regenerated and put through of ppt selection in two consecutive steps for three weeks. Altogether, 130 resistant plants were selected and potted out, but only 19 plants survived the acclimatisation. The $\mathrm{T}_{0}$ plants were grown up in the greenhouse at a day/night temperature of $18 / 16^{\circ} \mathrm{C}$ to avoid the cre-recombinase gene induction.

DNA was isolated from the leaves at the two leaf-stage (Zadoks scale 12). The specific products of uidA and bar gene have been identified in 16 and 17 plants, respectively (Fig. 2.). No transgene incorporation was detected in two plants $\left(3 \mathrm{~T}_{0} / 3,3 \mathrm{~T}_{0} / 7\right)$. Incomplete integration of the transformation cassette was observed in one plant $\left(3 \mathrm{~T}_{0} / 11\right)$, where only the bar gene was detected. Sixteen independent transgenic plants were identified with both genes. The progenies of these lines were grown up in greenhouse without any cold treatment.

Elimination of bar selection and cre- recombinase genes by cold inducible Cre-lox system In order to achieve selection marker gene removal, cold treatment was optimised for plants in different generations and developmental stages. Recombination frequency was determined by PCR using two different approaches. One was to detect the presence of bar and cre genes, while the other one was to screen for the recombination footprint. Primer pair 6 . is able to bind outside of the recombination part $(>4550 \mathrm{bp}$, Fig. 1) but due to the reaction conditions amplified fragment ( $350 \mathrm{bp})$ can only be detected when recombination has taken place.

In the first experiment, $38 \mathrm{~T}_{0}$ plants (Zadoks scale 14), after the seven days acclimatisation, were cold treated for two weeks at $+4^{\circ} \mathrm{C}$, and DNA were isolated from the leaves (Zadoks scale 16) two weeks after the cold treatment. Two transgenic lines carrying all the three transgenes were used as untreated controls. After the cold treatment the presence of all transgenes was studied by PCR primers (Table 1). The uidA gene was detected in all lines. 
Both the bar selection and the cre-recombinase genes were eliminated from seven plants the bar gene under cold treatment. (Table 2).

In the second experiment, $27 \mathrm{~T}_{0}$ plantlets were cold treated for two weeks at $+4^{\circ} \mathrm{C}$ immediately after in vitro phase (Zadoks scale 11) without any acclimatisation. DNA was again isolated two weeks later (Zadoks scale 14). Two transgenic lines carrying all the three transgenes were used as untreated controls (Table 2). The specific product of uidA (GOI) gene was identified in 24 lines as before cold treatment, and the histochemical staining was also positive (Online Resource 1). The bar selection and cre-recombinase genes were detected by 4 and 5 primer pairs in 12 and 15 lines respectively. Twelve transgenic lines lost both the bar selection and the cre-recombinase genes. The incorporation of the transformation cassette was incomplete in the $2 \mathrm{~T}_{0} / 4$ and $2 \mathrm{~T}_{0} / 25$ line, as only the recombination part of the cassette was detected before cold treatment. One of them $\left(2 \mathrm{~T}_{0} / 25\right)$ lost the bar and cre under cold. In three lines $\left(2 \mathrm{~T}_{0} / 1,2 \mathrm{~T}_{0} / 10,2 \mathrm{~T}_{0} / 11\right)$, which failed to incorporate the cre-recombinase gene, the bar gene still existed after the cold treatment. The recombination between the two lox sites occurred exclusively, in the cold treated plants carrying the cre-recombinase gene. Two weeks cold treatment at $+4^{\circ} \mathrm{C}$ induced the Cre/lox recombination system in $44.4 \%$ of the plants at one leaf stage (Zadoks scale 11).

The estimation of Cre/lox system activation based on the recombination footprint was higher (70\%) than based on the direct PCR amplifications of cre-recombinase and bar selection genes $(44.4 \%)$. Seven plants produced both the specific product of the remaining part of cassette and the bar selection genes in the second experiment. A remarkable difference could be observed in cre gene activation based on the results of two recombination event detection approaches.

Thirty-four $\mathrm{T}_{1}$ plants of three $\mathrm{T}_{0}$ plants $\left(3 \mathrm{~T}_{0} / 1,3 \mathrm{~T}_{0} / 2,3 \mathrm{~T}_{0} / 4\right)$ from the third transformation experiment were grown up in the greenhouse at $18 / 16{ }^{\circ} \mathrm{C}$ day/night temperature. In all the three transgenic lines the $T_{1}$ progenies originated from the main shoot and two side tillers. DNA was isolated form the plants in two leaves stages (Zadoks scale12), after that the wcs120 promoter-driven $\mathrm{cre}$-recombinase gene was activated by two weeks cold treatment at $+4^{\circ} \mathrm{C}$. Two weeks after the cold treatment DNA were isolated again (Zadoks scale14). The presence of uidA gene was tested by primer pair 1 (Table 3). The specific $450 \mathrm{bp}$ fragment was identified in three-quarters of offspring lines of $3 \mathrm{~T}_{0} / 2$ and $3 \mathrm{~T}_{0} / 4$ plants. The transgene segregation ratio was $3: 1$, which suggests that the gene was incorporated into the $T_{0}$ plant in one copy. In the case of $3 \mathrm{~T}_{0} / 1$, however $33 \%$ of the offspring lines carried the uidA gene. When the presence of the gene was examined in the descendants of the main shoot and the two side tillers separately, it turned out that three-quarter of the offsprings from the main shoot carried the uidA gene, but none of the tiller descendants contained it, which underline the chimeric nature of the $3 \mathrm{~T}_{0} / 1$ plant. Nevertheless the segregation of GOI for the progenies of the main shoot could again refer to one copy number of uidA gene. The presence or absence of the cre-recombinase gene was detected by primer pairs 5 in the $T_{1}$ lines containing the uidA gene. After the cold treatment the 600 bp long product was absent from the $66 \%$, $46 \%$ and $40 \%$ of $3 \mathrm{~T}_{0} / 1,3 \mathrm{~T}_{0} / 2$ and $3 \mathrm{~T}_{0} / 4$ transgenic lines, respectively. The average efficiency of cre-recombinase system was $51 \%$ in $\mathrm{T}_{1}$ progenies.

\section{Sequencing the incorporated DNA after recombination}

The sequence of the recombination footprint was determined in a recombination positive plant $\left(2 \mathrm{~T}_{0} / 8\right)$. For this, the PCR product amplified with $6 \mathrm{~F}$ and $6 \mathrm{R}$ primers was cloned into pCR2.1 vector (Invitrogen) and sequenced using M13 primers. The results indicated that a correct site-specific recombination has occurred in this plant (Fig. 3.). 


\section{Discussion}

The most frequently used vector during biolistic plant transformation is the circular plasmid, comprising undesirable bacterial DNA fragments along with the transgene, which can be responsible for several negative effects (Fu et al. 2000). To avoid these problems, linear minimal cassettes have been used for biolistic transformation of wheat immature embryos in our experiments. The vector carried the uidA (GOI) gene outside of the loxflanked region. Between the two lox sites, the recombination part, of the transformation cassette consisted of the cold inducible promoter-driven cre-recombinase gene and the bar selection marker gene, under the control of maize ubiquitin promoter. Although, only the minimal cassette was used in the present experiments, the results can be compared to our data published previously where the same genotype (cv. "Cadenza") and transformation method was applied. Transformation efficiency was slightly increased $(\sim 1.5 \%)$ using linear DNA rather than a circular plasmid, pAHC25 (0.8\%) (Tamás et al. 2009). This result is in accordance with previously published efficiency data for biolistic transformation of wheat. It was reported to be around $1.6 \%$ in the majority of the transformation experiments published (Li et al. 2012) although it reached 12-20\% in some case (Ogawa et al. 2008; Wright et al. 2001 ) or even exceeded $70 \%$ (Pellegrineschi et al. 2002), where whole circular plasmids were used. The transgene integration efficiencies were found to be the same (Fu et al. 2000) for the minimal cassette and for the whole plasmid transformation. On the contrary Uzé (1999) and Yao and co-workers (2007) observed increased transformation efficiency while using minimal cassette, instead of the whole plasmid (2.75 to $3.56 \%$ and 0.4 to $1.1 \%$, respectively). Tassy and co-workers (2014) obtained $2.5 \%$ transformation efficiency by cassette in wheat.

In our experiments, the segregation of GOI was determined in the 7-18 progenies of only three independent transgenic lines. Although all of them have one copy of the transgene, based on the 3:1 segregation ratio according to the Mendelian fashion in $\mathrm{T}_{1}$ generation, the accurate determination of the copy number would require higher numbers of the progeny of the independent transgenic lines. Simpler incorporation pattern and lower copy number were identified in other species also (Fu et al. 2000; Kumar et al. 2010; Loc et al. 2002). Yao et al. (2007) detected only one or two copies of transgenes in wheat. Tassy et al. (2014) identified only one copy of transgene in all transgenic wheat, bombarded by gen cassette. However there were no differences in the copy number either the plasmid or the minimal cassette was used in tomato and grapevine (Romano et al. 2003; Vidal et al. 2006).

Cre/lox auto-excision system was successfully applied for eliminating the undesirable parts of the transformation vectors as the selection marker gene, in many species (Gidoni et al. 2008; Tuteja et al. 2012). For the induction of cre, in auto-excision strategy, many types of promoters have already been tested with different efficiency (Chakraborti et al. 2008; ChongPerez et al. 2012, 2013; Russell et al. 1992). In our investigation a cold inducible promoter based Cre/lox mediated selection gene elimination system has been tested. Cold induction of wcs120 wheat promoter has been applied for cre gene activation, at one, two and four leafstage for two weeks at $+4^{\circ} \mathrm{C}$. This cold treatment proved to be sufficient for cre-recombinase gene activation, as the lox site flanked selection marker gene (bar) and recombinase gene (cre) were removed from transgenic plants, while the GOI (uidA) still remained in the wheat genome. We detected 17-60\% efficiency of marker gene elimination by the Cre/lox recombination system. The highest activation was observed when the plants were cold treated at one or two leaf-stage, which was independent of the progeny generation $\left(T_{0}\right.$ or $\left.T_{1}\right)$. Similar wide range of excision efficiency was reported in the literature using chemically, or heat shock induced or embryo specific Cre/lox systems (Chong-Perez et al. 2012; Liu et al. 2007; Zuo et al. 2001). Wang et al. (2005), however, reported lower variation in heat shock promoter activity. The efficiency of cre transgene activation may depend on the transgene 
incorporation site or on the developmental stage of the transgenic plants when cre gene recombinase genes were eliminated from several independent transgenic lines, indicating that the integration sites are probably of less importance.

Prolonged activation of cre-recombinase, causes aberration in plant development (Coppoolse et al. 2003), therefore the application of the transient expression or inducible promoters are required for $\mathrm{cre}$ gene activation. The Cre/lox recombination system based on a tissue specific promoter was successfully applied to eliminate selection gene with nearly the same efficiency as in our experiment (Bai et al. 2008; Hu et al. 2013). Mlynárová et al. (2006) and Moravčíková et al. (2008) reported efficiency as high as $99 \%$ and $96 \%$ using microsporeand seed specific cruciferin promoter controlled Cre/lox excision of the marker gene. The application of inducible promoters is another alternative of controlled gene expression. Cre induction had been demonstrated by expressing this gene under the control of a chemically inducible promoter with 29-66\% efficiency (Sreekala et al. 2005). Ma and co-workers (2008) applied approximately the same recombination vector structure as in the present work with nearly the same efficiency (38\%), but Cre/lox- recombination system was under the control of the salicylic-acid-regulated promoter. The heat shock-inducible Cre/lox system is the most extensively applied in many species. The efficiency of this system differed from our results. The lowest level has been detected in potato shoot internodes (5-14\%) (Cuellar et al. 2006), Wang et al. (2005) have reached $70-80 \%$ Cre/lox activity in tobacco seed and leaf, while the excision rate has even reached $100 \%$ in tobacco seedlings (Liu et al. 2005). Heat shock can cause damage in wheat tissues therefore it is not the most proper way of inducing gene expression. Although there is no information about cold induced Cre/lox auto-excision system in the literature it seems to be an adequate way to induce site-specific excision of undesirable genes. Cold-inducible cor15a promoter was used with success in sugarcane transformation (Belintani et al. 2012). Quellet et al (1998) proved the strict cold regulation of wcs120 promoter. In our study the same temperature was applied as in mentioned work of Quellet et al. (1998).

Estimation of Cre/lox system activation efficiency was higher (70\%) based on the recombination footprint, than based on elimination of cre-recombinase and bar selection genes (44\%). The explanation for this can be that the recombination was not complete in the whole plant in $26 \%$ of the transgenic lines. Recombination took place in some cells, while the $\mathrm{Cre} / \mathrm{lox}$ system failed to activate in the others resulting in chimeric $\mathrm{T}_{0}$ plants. Another source of ambivalent character of plant can be that the cells emerging before activation of the autoexcision system contain the bar and cre genes while the latter formed celles may lack of the bar and cre genes. The selection gene elimination by Cre/lox system resulted chimeric plants in other species as well. The ratio of chimeric plants may depend on the genome size, developmental stage (Russell et al. 1992) and the promoter of cre gene (Bai et al. 2008). In summary, the efficiency of the cold inducible Cre/lox recombination system presented here is comparable with the other constitutive, organ specific or inducible promoter based Cre/lox mediated transgene elimination methods.

The recombination activity in $\mathrm{T}_{1}$ progenies was found to be around $50 \%$, which was very similar to the level measured in the $\mathrm{T}_{0}$ transgenic lines. Blechl and co-workers (2012) carried out a Bxb1 recombinase mediated site specific deletion in wheat. All $\mathrm{T}_{1}$ descendants, carring Bxb1 recombinase, had recombinase activity underlining that the recombinase gene retains its activity in the subsequent generations. Moreover, we could induce the wcs120 promoter in the $\mathrm{T}_{1}$ generation with the same efficiency as in the $\mathrm{T}_{0}$ generation.

This is the first report of the simultaneous application of the minimal gene cassette and cold inducible Cre/lox recombination system in wheat. This approach provides a new effective technique to produce selection marker gene-free transgenic wheat lines immediately 
after tissue culture or from the subsequent transgenic generation. The cold treatment necessary for activating the marker gene elimination did not require any additional steps in the plant regeneration/growing, because it took place parallel to the saturation of the vernalisation requirements of the cereals with winter growth habit. The application of this method prevents the gene-flow by pollen and seed, because the selection and recombinase gene are eliminated before pollen development, therefore reducing the risk of GM plants. Our system represents a stable and efficient biolistic wheat transformation system for generating transgenic wheat plants without undesirable sequences: the plasmid backbone and selection marker genes.

\section{Acknowledgement}

The work was funded by the OTKA projects No. 68659 .

\section{References}

Akbudak AM, Srivastava V (2011) Improved FLP recombinase, FLPe, efficiently removes marker gene from transgene locus developed by Cre-lox mediated site-specific gene integration in rice. Mol. Biotechnol. 49:82-89 doi: 10.1007/s12033-011-9381-y

Albert H, Dale EC, Lee E, Ok DW (1995) Site-specific integration of DNA into wild-type and mutant lox sites placed in the plant genome. Plant J 7:649-659.

Bai X, Wang Q, Chengcai C (2008) Excision of a selective marker in transgenic rice using a novel Cre/loxP system controlled by a floral specific promoter. Transgenic Res 17:1035-1043. doi: 10.1007/s11248-008-9182-7

Belintani NG, Guerzoni JTS, Moreira RMP, Vieira LGE (2012) Improving low-temperature tolerance in sugarcane by expressing the ipt gene under a cold inducible promoter. Biol. Plantarum 56:71-77.

Blechl A, Lin J, Shao M, Thilmony R, Thomson J (2012) The Bxb1 Recombinase mediates site-specific deletion in transgenic wheat. Plant Mol Biol Rep 30:1357-1366. doi: 10.1007/s11105-012-0454-2

Chakraborti D, Sarkar A, Mondal HA, Schuermann D, Hohn B, Sarmah BK, Das S (2008) Cre/lox system to develop selectable marker free transgenic tobacco plants conferring resistance against sap sucking homopteran insect. Plant Cell Rep 27:1623-1633. doi: 10.1007/s00299-008-0585-y

Chong-Perez B, Kosky RG, Reyes M, Rojas L, Ocãna B, Tejeda M, Perez B, Angenon G (2012) Heat shock induced excision of selectable marker genes in transgenic banana by the Cre-lox site-specific recombination system. J Biotechnol 159:265-273. doi: 10.1016/j.jbiotec.2011.07.031

Chong-Pérez B, Reyes M, Rojas L, Ocaña B, Ramos A, Kosky RG, Angenon G (2013) Excision of a selectable marker gene in transgenic banana using a Cre/lox system controlled by an embryo specific promoter. Plant Mol. Biol. 83: 143-152. doi: $10.1007 / \mathrm{s} 11103-013-0058-8$

Coppoolse ER, de Vroomen MJ, Roelofs D, Smit J, van Gennip F, Hersmus BJM, Nijkamp HJ, van Haaren MJJ (2003) Cre recombinase expression can result in phenotypic aberrations in plants. Plant Mol. Biol. 51: 263-279.

Cotsaftis O, Sallaud C, Breitler JC, Meynard D, Greco R, Pereira A, Guiderdoni E (2002) Transposon-mediated generation of T-DNA-and marker-free rice plants expressing a Bt endotoxin gene. Mol Breed 10:165-180.

Cuellar W, Gaudin A, Solórzano D, Casas A, Nopo L, Chudalayandi P, Medrano G, Kreuze J, Ghislain M (2006) Self-excision of the antibiotic resistance gene nptII using a heat 
inducible Cre-loxP system from transgenic potato. Plant Mol. Biol 62: 71-82. doi: 10.1007/s11103-006-9004-3

Fu X, Duc LT, Fontana S, Bong BB, Tinjuangjun P, Sudhakar D, Twyman RM, Christou1 P, Kohli A (2000) Linear transgene constructs lacking vector backbone sequences generate low-copy-number transgenic plants with simple integration patterns. Transgenic Res 9:11-19.

Gidoni D, Srivastava V, Carmi N (2008) Site-specific excisional recombination strategies for elimination of undesirable transgenes from crop plants. In Vitro Cell. Dev. Biol.-Plant 44:457-467. doi: 10.1007/s11627-008-9140-3

Gilbertson L (2003) Cre-lox recombination: cre-ative tools for plant biotechnology. Trends Biotechnol 21:550-555. doi:10.1016/j.tibtech.2003.09.011

Hoa TTC, Bong BB, Huq E, Hodges TK (2002) Cre/lox site-specific recombination controls the excision of a transgene from the rice genom. Theor Appl Genet 104:518-525. doi: $10.1007 / \mathrm{s} 001220100748$

Hoess RH, Abremski K (1985) Mechanism of strand cleavage and exchange in the Cre-lox site-specific recombination system. Journal of Mol Biol 181:351-362

Houde, M., Danyluk, J., Laliberté, J.-F., Rassart, E., Dhindsa, R.S., Sarhan,F. (1992) Cloning, characterization, and expression of a cDNA encoding a 50-kilodalton protein specifically induced by cold acclimation in wheat. Plant Physiol 99:1381-1387

Hu Q, Kononowicz-Hodges H, Nelson-Vasilchik K, Viola D, Zeng P, Liu H, Kausch AP, Chandlee JM, Hodges TK, Luo H (2008) FLP recombinase-mediated site-specific recombination in rice. Plant Biotechnol $\mathrm{J}$ 6:176-188. doi: 10.1111/j.1467652.2007.00310.X

Hu Z, Ding X, Hu S, Sun Y, Xia L (2013) Tissue-specifically regulated site-specific excision of selectable marker gene in bivalent insecticidal, genetically-modified rice. Biotechnol Lett 35:2177-2183 doi: 10.100/s10529-013-1310-7

Kempe K, Rubtsova M, Berger C, Kumlehn J, Schollmeier C, Gils M (2010) Transgene excision from wheat chromosomes by phage phiC31 integrase. Plant Mol Biol 72(6):673-687. doi:10.1007/s11103-010-9606-7

Kittiwongwattana C, Lutz K, Clark M, Maliga P (2007) Plastid marker gene excision by the phiC31 phage site-specific recombinase. Plant Mol Biol 64:137-143. doi: 10.1007/s11103-007-9140-4

Kopertekh L, Jüttner G, Schiemann J (2004) PVX-Cre-mediated marker gene elimination from transgenic plants. Plant Mol Biol 55:491-500,

Kosová K, Vítámvás P, Prášil IT (2007) The role of dehydrins in plant response to cold. Biol Plant 51:601-617.

Kosová K, Vítámvás P, Prášil IT (2011) Expression of dehydrins in wheat and barley under different temperatures. Plant Sci 180:46-52. doi: 10.1016/j.plantsci.2010.07.003

Kosová K, Vítámvás P, Prášilová P, Prášil IT (2013) Accumulation of WCS120 and DHN5 proteins in differently frost-tolerant wheat and barley cultivars grown under a broad temperature scale. Biol Plant 57: 105-112. doi: 10.1007/s10535-012-0237-5

Kumar S, Arul L, Talwar D (2010) Generation of marker-free Bt transgenic indica rice and evaluation of its yellow stem borer resistance. J Appl Genet 51:243-257

Li J, Xingguo Y, Baoyan A, Lipu D, Huijun X (2012) Genetic transformation of wheat: current status and future prospects. Plant Biotechnol Report 6: 183-193. doi: 101007/s11816-011-0213-0

Limin AE, Houde M, Chauvin LP, Fowler DB, Sarhan F (1995) Expression of the coldinduced wheat gene Wcs120 and its homologs in related species and interspecific combinations. Genome 38:1023-1031. doi: 10.1139/g95-135 
Liu HK, Yang C, Wei ZH (2005) Heat shock-regulated site-specific excision of extraneous DNA in transgenic plants. Plant Sci 168: 997-1003. doi: 10.1016/j.plantsci.2004.11.021

Loc TN, Tinjuangjun P, Gatehouse MRA, Christou P, Gatehouse AJ (2002) Linear transgene constructs lacking vector backbones sequences generate transgenic rice plants which accumulate higher levels of proteins conferring insect resistance. Mol Breed 9:231244

Lyznik LA, Rao KV, Hodges TK (1996) FLP-mediated recombination of FRT sites in the maize genome. Nucleic Acids Res 24:3784-3789. doi:10.1093/nar/24.19.3784

Ma B, Duan X, Ma C, Niu J, Zhang H, Pan L (2008) Salicylic-Acid-Induced Self-excision of the Marker Gene nptII from Transgenic Tomato Using the Cre-loxP System. Plant Mol Biol Rep 26:199-212. doi 10.1007/s11105-008-0039-2

Matthews PR, Wang MB, Waterhouse PM, Thornton S,. Fieg SJ, Gubler F, Jacobsen JV (2001) Marker gene elimination from transgenic barley, using co-transformation with adjacent 'twin T-DNAs' on a standard Agrobacterium transformation vector. Mol Breed 7: 195-202, 2001.

Mlynárová L, Conner AJ, Nap JP (2006) Directed microspore-specific recombination of transgenic alleles to prevent pollen-mediated transmission of transgenes. Plant Biotechnol J 4: 445-452. doi: 10.1111/j.1467-7652.2006.00194.x.

Nandy S, Srivastava V (2012) Marker-free site-specific gene integration in rice based on the use of two recombination systems. Plant Biotech. Journal 10:904-912. doi:10.1111/j.1467-7652.2012.00715.x

Ogawa T, Kawahigashi H, Toki S, Handa H (2008) Efficient transformation of wheat by using a mutated rice acetolactate synthase gene as a selectable marker. Plant Cell Rep 27:1325-1331. doi: 10.1007/s00299-008-0553-6

Pellegrineschi A, Noguera LM, Skovmand B, Brito RM, Velazquez L, Salgado MM, Hernandez R, Warburton M, Hoisington D (2002) Identification of highly transformable wheat genotypes for mass production of fertile transgenic plants. Genome 45:421-430. doi: 10.1139/g01-154

Quellet F, Vazquez-Tello A, Sarhan F (1998) The wheat wcs120 promoter is cold-inducible in both monocotyledonous and dicotyledonous species. FEBS Letters 423:324-328.

Reed J, Privalle L, Powell ML, Meghji M, Dawson J, Dunder E, Sutthe J, Wenck A, Launis K, Kramer C (2001) Phosphomannose isomerase: an efficient selectable marker for plant transformation. In Vitro Cell Dev Biol-PL 37:127-132.

Romano A, Raemakers K, Bernardi J, Visser R,Mooibroek H (2003) Transgene organization in potato after particle bombardmentmediated (co-)transformation using plasmids and gene cassettes. Transgenic Res 12:461-473.

Russell SH, Hoopes JL, Odell JL (1992) Directed excision of a transgene from the plant genome. Mol Gen Genet 234:49-59

Sarhan F, Ouellet F, Vazquez-Tello A (1997) The wheat WCS120 gene family. A useful model to understand the molecular genetics of freezing tolerance in cereals. Physiol. Plant. 101:439-445.

Shen YG, Zhang WK, He SJ, Zhang JS, Liu Q, Chen SY (2003) An EREBP/AP2-type protein in Triticum aestivum was a DRE-binding transcription factor induced by cold, dehydration and ABA stress. Theor Appl Genet 106:923-930. doi: 10.1007/s00122002-1131-X

Sparks CA, Jones HD (2004) Transformation of wheat by biolistics. In: Curtis IS (ed) Transgenic crops of the world - essential protocols, Kluwer Publishers, Dordrecht, pp $19-34$ 
Sreekala C, Wu L, Gu K, Wang D, Tian D, Yin Z (2005) Excision of a selectable marker in transgenic rice (Oryza sativa L.) using chemically regulated Cre/loxP system. Plant Cell Rep 24:86-94. doi 10.1007/s00299-004-0909-5

Sternberg N, Sauer B, Hoess R, Abremski K (1986) Bacteriophage P1 cre gene and its regulatory region. Evidence for multiple promoters and for regulation by DNA methylation. J.Mol. Biol. 187: 197-212.

Tamás C, Szucs P, Rakszegi M, Tamás L, Bedő Z (2004) Effect of combined changes in culture medium and incubation conditions on the regeneration from immature embryos of elite varieties of winter wheat. Plant Cell Tissue and Org Cul 79:39-44.

Tamás C, Kisgyörgy BN, Rakszegi M, Wilkinson MD, Yang MS, Láng L, Tamás L, Bedo Z (2009) Transgenic approach to improve wheat (Triticum aestivum L.) nutritional quality. Plant Cell Rep 28:1085-1094. doi: 10.1007/s00299-009-0716-0

Tassy C, Partier A, Beckert M, Feuillet C, Barret P (2014) Biolistic transformation of wheat: increased production of plants with simple insertions and heritable transgene expression. Plant Cell Tiss Org. Cult 119:171-181. doi: 10.1007/s11240-014-0524-2

Thomashow MF (1999) Plant cold acclimation: Freezing tolerance genes and regulatory mechanisms, Annu. Rev. Plant Physiol. Plant Mol. Biol. 50: 571-599.

Tuteja N, Verma S, Sahoo RK, Raveendar S, Reddy IBL (2012) Recent advances in development of marker-free transgenic plants: Regulation and biosafety concern. Journal of Biosciences 37:167-197.

Uze` M, Potrykus I, Sautter C (1999) Single-stranded DNA in the genetic transformation of wheat (Triticum aestivum L.): transformation frequency and intergration pattern. Theor Appl Genet 99:487-495.

Vidal JR, Kikkert JR, Donzelli BD, Wallace PG, Reisch BI (2006) Biolistic transformation of grapevine using minimal gene cassette technology. Plant Cell Rep25: 807-814. doi: $10.1007 / \mathrm{s} 00299-006-0132-7$

Vitámvás P, Prášil IT(2008) WCS120 protein family and frost tolerance during cold acclimation, deacclimation and reacclimation of winter wheat. Plant Physiol and Biochem 46:970-976 doi:10.1016/j.plaphy.2008.06.006

Wang Y; Chen B; Hu Y; Li J; Lin Z (2005) Inducible excision of selectable marker gene from transgenic plants by the cre/lox site-specific recombination system. Transgenic Res 14:605-614. doi: 10.1007/s11248-005-0884-9

Wright M, Dawson J, Dunder E, Suttie J, Reed J, Kramer C, Chang Y, Novitzky R, Wang H, Artim-Moore L (2001) Efficient biolistic transformation of maize (Zea mays L.) and wheat (Triticum aestivum L.) using the phosphomannose isomerase gene, pmi, as the selectable marker. Plant Cell Rep 20:429-436. doi: 10.1007/s002990100318

Wu H, Sparks C, Amoah B, Jones HD (2003) Factors influencing successful Agrobacteriummediated genetic transformation of wheat. Plant Cell Rep 21:659-668. doi: 10.1007/s00299-002-0564-7

Yao Q, Cong L, He G, Chang J, Li K, Yang G (2007) Optimization of wheat cotransformation procedure with gene cassettes resulted in an improvement in transformation frequency. Mol Biol Rep 34:61-67. doi: 10.1007/s11033-006-9016-8

Zhu Z, Wu R (2008) Regeneration of transgenic rice plants using high salt for selection without the need for antibiotics or herbicides. Plant Sci 174:519-523. doi: 10.1016/j.plantsci.2008.01.017

Zuo J, Niu QW, Moller SG, Chua NH (2001) Chemical-regulated, site-specific DNA excision in transgenic plants. Nat Biotechnol 19:157-161. doi:10.1038/84428 
Fig. 1: Schematic representation of the assembled minimal DNA-construct ligated into NotI site of pWBVec8. Primer binding sites are also shown. The new DNA construct contained the recombination cassette flanked by mutant lox sites, lox66 and 71, and included the coding sequence of cre recombinase gene (Gene Bank accession number: X03453.1) under the control of wheat wcs120 promoter (AF031235) and the selectable marker gene bar under the control of maize ubiquitin promoter. The gene of interest (GOI), the maize ubiquitin promoter-driven uidA was inserted outside of the lox sites. All the three genes (cre, bar, uidA) were fused to Agrobacterium tumefaciens nos terminator.

Fig. 2: The presence or absence of $u i d A(\mathrm{GOI})$ and bar selection genes in $\mathrm{T}_{0}$ transgenic lines from third experiment.

Fig. 3: Sequence of the recombined region (upper lines) aligned to the expected sequence (lower lines). 


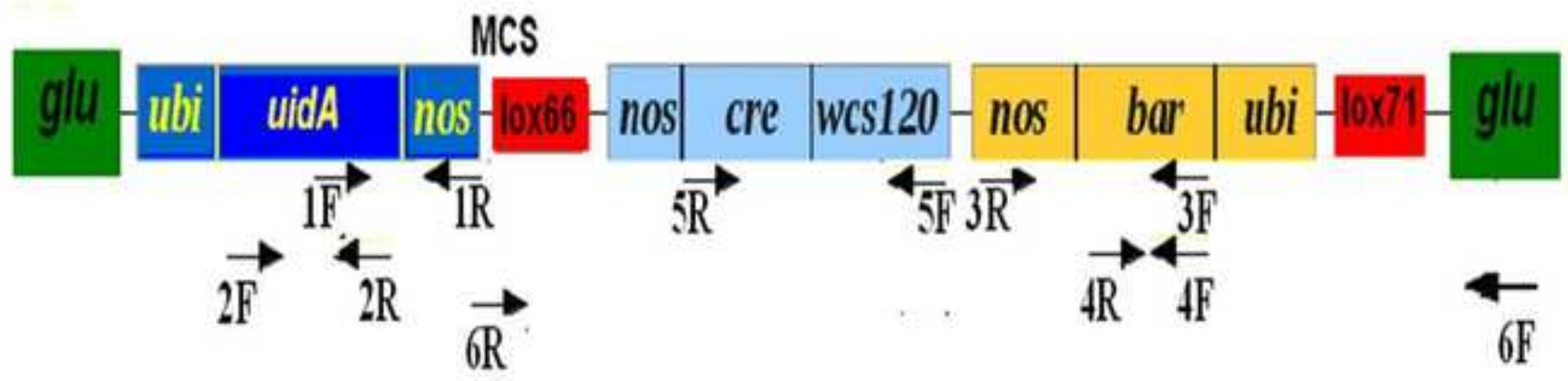




\section{igure2}

Click here to download Figure: fig2.pdf

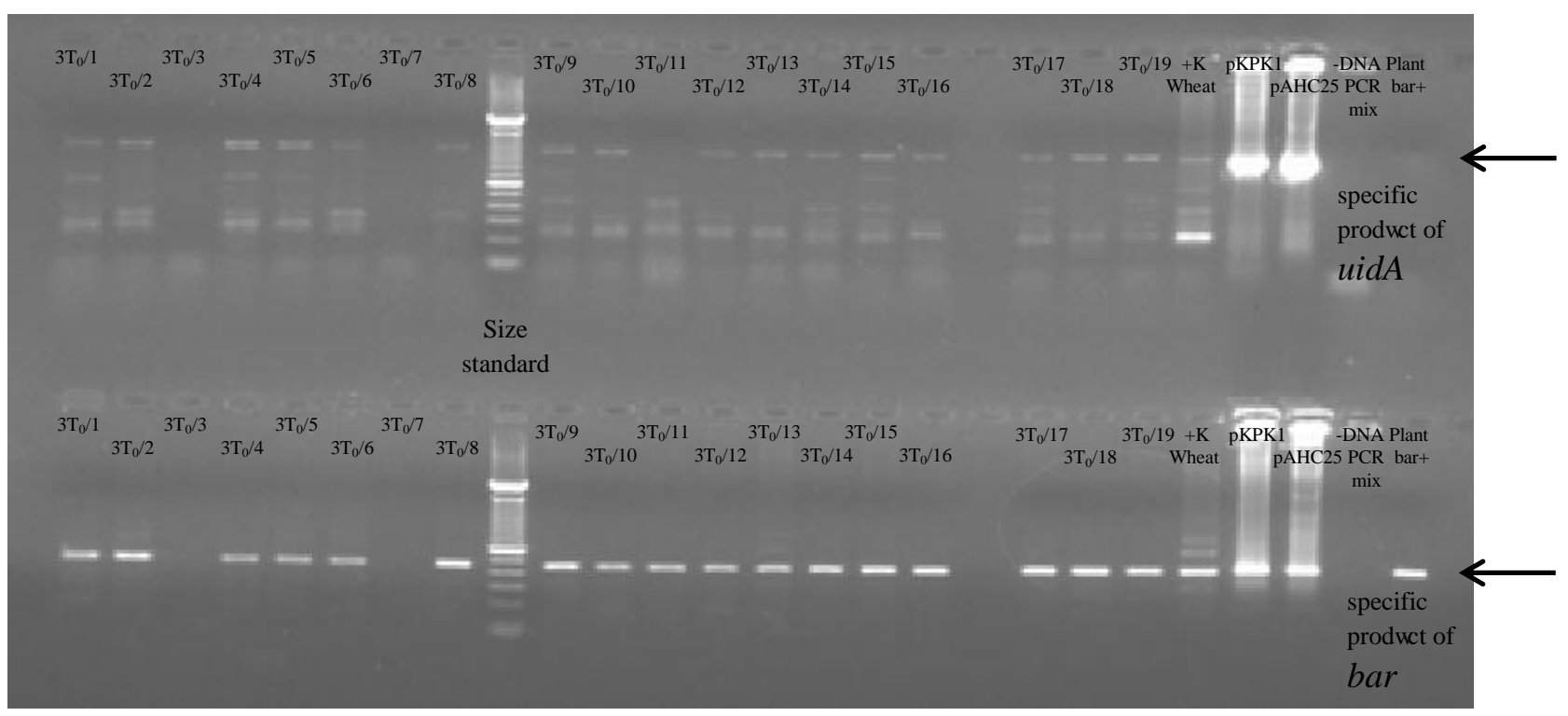




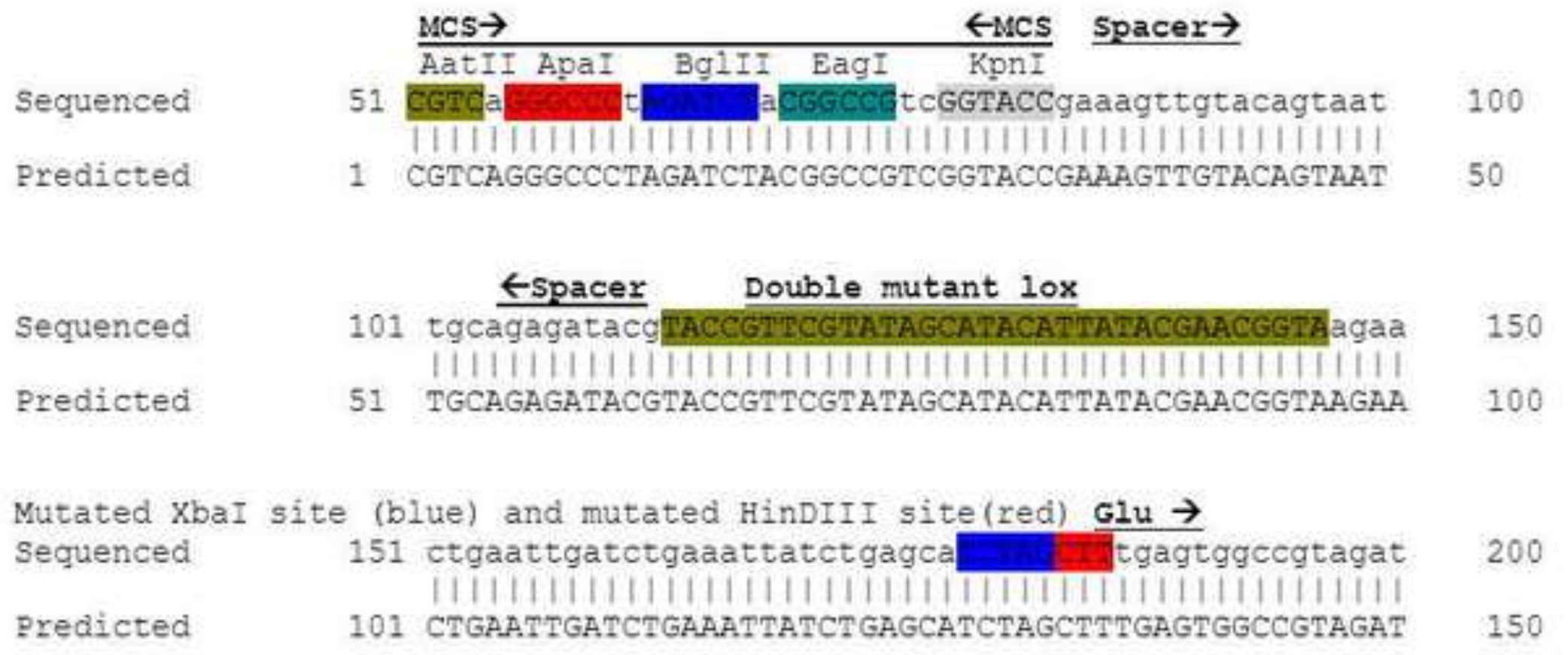


Table 1: PCR primers for uidA (GOI), bar selection, cre-recombinase genes and mutant lox site detection.

\begin{tabular}{|c|c|c|c|c|}
\hline Gene & Primer & Primer sequence & $\begin{array}{c}\text { Anealing } \\
\text { temperature }\end{array}$ & Product size \\
\hline \multirow[t]{4}{*}{ uidA } & $1 F$ & 5'-ACTGGCATGAACTTCGGTG-3' & $58^{\circ} \mathrm{C}$ & \multirow[t]{2}{*}{450 bp } \\
\hline & $1 R$ & 5'-TAACATAGAT GACACCGC-3’' & $58^{\circ} \mathrm{C}$ & \\
\hline & $2 F$ & 5'-AGTGTACGTATCACCGTTTGTGTGAAC-3’ & $62{ }^{\circ} \mathrm{C}$ & \multirow[t]{2}{*}{$1051 \mathrm{bp}$} \\
\hline & $2 R$ & 5'-ATCGCCGCTTTGGACATACCATCCGTA-3' & $62{ }^{\circ} \mathrm{C}$ & \\
\hline \multirow[t]{4}{*}{ bar } & $3 F$ & 5'-CACGCTCTAC ACCCACCTG-3' & $58^{\circ} \mathrm{C}$ & \multirow[t]{2}{*}{500 bp } \\
\hline & $3 R$ & 5'-ATAATTTATCCTAGTTTGCG-3' & $58^{\circ} \mathrm{C}$ & \\
\hline & $4 F$ & 5'-GTCTGCACCATCGTCAACC-3' & $57^{\circ} \mathrm{C}$ & \multirow[t]{2}{*}{444 bp } \\
\hline & $4 R$ & 5'-GAAGTCCAGCTGCCAGAAAC-3' & $57^{\circ} \mathrm{C}$ & \\
\hline \multirow[t]{2}{*}{ cre } & $5 F$ & 5'-TAGTAGATTTCCCGAGTGAG-3' & $50^{\circ} \mathrm{C}$ & \multirow[t]{2}{*}{600 bp } \\
\hline & $5 R$ & 5'-TATCTTTAACCСTGATCCTG-3' & $50^{\circ} \mathrm{C}$ & \\
\hline \multirow{2}{*}{$\begin{array}{c}\text { mutant lox } \\
\text { site }\end{array}$} & $6 F$ & 5' GATTTGCTGCTCGTATTGTC3' & $55^{\circ} \mathrm{C}$ & \multirow[t]{2}{*}{350 bp } \\
\hline & $6 R$ & 5' TCGGTTGGAAAAGCGCAG 3' & $55^{\circ} \mathrm{C}$ & \\
\hline \multirow[t]{2}{*}{ Ppd-Dl } & $F$ & 5'-GATGAACATGAAACGGG-3' & $56^{\circ} \mathrm{C}$ & \multirow[t]{2}{*}{320 bp } \\
\hline & $R$ & 5'-GTCTAAATAGTAGGTACTAGG-3' & $56^{\circ} \mathrm{C}$ & \\
\hline
\end{tabular}


Table 2: Presence of uidA (GOI), bar selection and cre-recombinase genes before or after cold treatment in the transgenic lines.

\begin{tabular}{|c|c|c|c|c|c|c|c|c|c|}
\hline \multirow[t]{2}{*}{ Experiment } & \multirow[t]{2}{*}{$\begin{array}{l}\text { No. } \\
\text { transgenic } \\
\text { lines }\end{array}$} & \multicolumn{3}{|c|}{$\begin{array}{l}\text { Presence } \begin{array}{r}\text { of } \\
\text { transgenes before } \\
\text { cold treatment }\end{array} \\
\end{array}$} & \multicolumn{3}{|c|}{$\begin{array}{l}\text { Presence } \begin{array}{r}\text { of } \\
\text { after } \\
\text { cold treatment }\end{array} \\
\end{array}$} & \multirow[t]{2}{*}{$\begin{array}{l}\text { Recom- } \\
\text { bination }\end{array}$} & \multirow[t]{2}{*}{$\begin{array}{l}\text { No. bar and cre } \\
\text { gene free plants }\end{array}$} \\
\hline & & uidA & cre & bar & uidA & cre & bar & & \\
\hline 1 & 38 & 38 & 36 & 38 & 38 & 29 & 31 & 7 & 7 \\
\hline 2 & 27 & 24 & 22 & 25 & 24 & 10 & 13 & 19 & 12 \\
\hline 3 & 19 & 16 & & 17 & & & & & \\
\hline
\end{tabular}


Click here to download Table: Table 3.docx

Table 3.: Result of cold treatment in $\mathrm{T}_{1}$ offspring lines

\begin{tabular}{|c|c|c|c|c|c|}
\hline Ancestor lines & \multirow{2}{*}{$\begin{array}{c}\text { Treated } \mathbf{T}_{\mathbf{1}} \\
\text { plants }\end{array}$} & \multicolumn{2}{|c|}{$\begin{array}{c}\text { uidA + } \\
\text { plants }\end{array}$} & \multicolumn{2}{c|}{$\begin{array}{c}\text { Plants lost } \\
\text { cre-recombinase }\end{array}$} \\
\cline { 3 - 6 } & & No. & \% of total & No. & \% of total \\
\hline $\mathbf{3 T}_{\mathbf{0}} / \mathbf{1}$ & 9 & 3 & 33.33 & 2 & 66.66 \\
\hline $\mathbf{3 T}_{\mathbf{0}} / \mathbf{2}$ & 18 & 12 & 77.77 & 6 & 45.15 \\
\hline $\mathbf{3 T}_{\mathbf{0}} \mathbf{/ 4}$ & 7 & 5 & 71.42 & 2 & 40.00 \\
\hline
\end{tabular}

